\title{
PERISTIWA PEMBERANTASAN PGRS-PARAKU DI KALIMANTAN BARAT TAHUN 1967 (KAJIAN TEORI HEGEMONI GRAMSCI UNTUK PEMBELAJARAN SEJARAH LOKAL)
}

\author{
Yulita Dewi Purmintasari \\ Jurusan Pendidikan Sejarah, STKIP PGRI Pontianak
}

\begin{abstract}
ABSTRAK
Tujuan dari penelitian ini adalah untuk mendapatkan informasi yang objektif mengenai peristiwa pemberantasan PGRS/Paraku di Kalimantan Barat, analisis teori hegemoni Gramsci terhadap peristiwa pemberantasan PGRS/Paraku, pembelajaran sejarah lokal melalui materi peristiwa pemberantasan PGRS-Paraku. Metode yang digunakan dalam penelitian ini adalah metode deskriptif dengan bentuk studi kasus terpancang. Sumber data dalam penelitian ini adalah informan atau narasumber yang terdiri dari dosen dan mahasiswa. Teknik pengumpul data berupa observasi langsung dengan alat pengumpul data panduan observasi, komunikasi langsung dengan alat pengumpul data panduan wawancara.

Berdarkan pembahasan penelitian yang telah diuraikan di atas maka dapat ditarik kesimpulan bahwa PGRS/Paraku dibentuk ketika terjadi konfrontasi antara Indonesia Malaysia, dimana Soekarno tidak setuju terhadap pembentukan Federasi Malaysia. Sikap Soekarno ini didukung oleh rakyat Kalimantan Utara. Namun ketika Orde Baru, kondisi menjadi berubah. PGRS/Paraku yang dulunya menjadi garda terdepan dalam konfrontasi akhirnya diperangi dan dibumihanguskan. Teori hegemoni Gramsci membantu dalam menganalisis peristiwa pemberantasan PGRS/Paraku. Hegemoni merupakan alat untuk melanggengkan kekuasaan. Dalam penumpasan PGRS/Paraku sebagai bentuk kecil hegemoni di Kalimantan Barat, tindakan kekerasan yang bersifat memaksa dilakukan oleh militer, dalam hal ini adalah angkatan darat. Soeharto memberi kontrol yang sangat ketat untuk dapat mengendalikan situasi di lapangan. Masyarakat Dayak di daerah perbatasan menghimpun kekuatan bersamasama ABRI melawan komunis yang telah memecah belah mereka dan menumpas PGRS/Paraku.

Kajian peristiwa pemberantasan PGRS/Paraku melalui kajian hegemoni Gramsci dapat menjadi suatu materi pembelajaran sejarah lokal. Mahasiswa dapat menggali sejarah lokal yang ada dan dapat menambah pengetahuan baik bagi mahasiswa maupun dosen serta dapat meningkatkan rasa nasionalisme pada mahasiswa generasi yang akan datang. Adapun saran yang dapat disampaikan bahwa penggunaan sejarah lokal suatu daerah harus terus dikembangkan agar pembelajaran sejarah tidak hanya mengkaji sejarah nasional saja. Hal ini dapat meningkatkan jiwa nasionalisme dan patriotisme.
\end{abstract}

Kata Kunci : PGRS/Paraku, Hegemoni Gramsci 


\section{PENDAHULUAN}

Kalimantan Barat sebagai bagian dari Indonesia memiliki andil yang besar dalam percaturan politik di Indonesia. Kondisi ini akan terlihat pada saat adanya rencana pembentukan Negara Federasi Malaysia. Suatu rencana untuk menggabungkan negara-negara bekas jajahan Inggris dalam satu payung. Presiden Soekarno berpendapat bahwa Malaysia hanya sebuah boneka Inggris, dan konsolidasi Malaysia hanya akan menambah kontrol Inggris di kawasan ini Asia Tenggara, sehingga mengancam kedaulatan Indonesia.

Soekarno melancarakan seruan Ganyang Malaysia untuk mrnyelamatkan rakyat Malaysia dari bahaya neokolim Inggris.Penentangan ini ditanggapai Soekarno dengan memberikan dukungan pada Pasukan Gerilya Rakyat Serawak (PGRS) dan Pasukan Rakyat Kalimantan Utara (Paraku). Orang-orang yang tergabung dalam PGRS-Paraku sebagian besar adalah etnis Tionghoa dan prokomunis. Namun setelah terjadinya tragedi G 30 S tahun 1965, kondisi politik di Indonesia berubah. Peristiwa tersebut melemahkan dominasi PKI dalam pemerintahan.
Soeharto segera menyelesaikan masalah konfrontasi Indonesia-Malaysia dengan ditandatanganinya Jakarta Accord. Pemeritahan Soeharto segera menumpas PGRS-Paraku, hal ini sesuai dengan Tap MPRS No.XXV/MPRS/1966 yang melarang ajaran marxisme-leninisme di Indonesia. Operasi-operasi penumpasan yang dilakukan Tentara Indonesia berhasil melumpuhkan PGRS-Paraku.

Penetrasi ideologi sangat kental sekali dalam Pemberantasan PGRSParaku yang menunjukkan adanya hegemoni dan dominasi suatu kekuasaan penguasa. Sangat menarik melihat seperti apa hegemoni kekuasaan yang terjadi dalam pemerantasan PGRS-Paraku melalui kacamata teori hegemoni Gramsci. Kajian ini akan menambahkan khasanah kajian sejarah lokal di Kalimantan Barat. Maka dari itu peneliti tertarik untuk melakukan penelitian yang mengkaji peristiwa pemberantasan PGRS-Paraku yang dikaji dengan teori hegemoni Gramsci yang menjadi salah satu pembahasan dalam materi sejarah lokal.

\section{KAJIAN TEORI}

\section{Teori Hegemoni Gramsci}

Teori hegemoni dari Gramci dibangun di atas premis pentingnya ide 
dan tidak mencukupinya kekuatan fisik belaka dalam kontrol sosial politik. Menurut Gramci, agar yang dikuasai mematuhi penguasa, yang dikuasai tidak hanya harus merasa mempunyai dan menginternalisasi nilai-nilai serta norma penguasa, lebih dari itu mereka juga harus memberi persetujuan atas subordinasi mereka. Inilah yang dimaksud Gramci dengan "hegemoni” atau menguasai dengan "kepemimpinan moral dan intelektual” secara konsensual. Dalam kontek ini, Gramci secara berlawanan mendudukkan hegemoni, sebagai satu bentuk supremasi satu kelompok atau beberapa kelompok atas yang lainnya, dengan bentuk supermasi lain yang ia namakan "dominasi" yaitu kekuasaan yang ditopang oleh kekuatan fisik.

\section{Pemberantasan PGRS/Paraku}

Menjelang akhir 1965, Jendral Soeharto memegang kekuasaan di Indonesia setelah berlangsungnya G30S/PKI. Oleh karena konflik domestik ini, keinginan Indonesia untuk meneruskan perang dengan Malaysia menjadi berkurang dan peperangan pun mereda. Tetapi setelah Soeharto dapat duduk dalam tampuk kepemimpinan Indonesia, berlangsung pembantaian orang-orang yang dianggap komunis.
Hal ini dikarenakan bedanya pandangan idiologi Soeharto dengan komunis. Usaha untuk menghabisi komunis di Kalimantan Barat baru terjadi setelah adanya rekonsiliasi dengan Malaysia.

Rekonsialisasi dan Perubahan politik menyebabkan Indonesia tidak lagi sejalan dengan politik PGRSParaku. Justru menciptakan situasi yang kacau, menjadikan PGRS/Paraku sebagai pendatang liar di daerah perbatasan Serawak dan Kalimantan Barat. Mereka hidup bergerilya, terjepit di antara tentara Indonesia dan Malaysia. Operasi untuk menumpas gerilyawan PGRS/Paraku berjalan sangat sulit, karena PGRS/Paraku selalu menghindari pertempuran terbuka. Dengan jumlah personil dan persenjataan yang terbatas mereka hanya beroperasi di hutan-hutan. Orangorang yang simpati kepada PGRS/Paraku masuk ke hutan Kalimantan Barat untuk bergabung dengan mereka di sana. Bulan Juli 1967 PGRS-Paraku menyerang pangkalan udara militer Indonesia di Sanggauledo .Beberapa perwira dan staffnya dibunuh. Mereka juga merebut senjata dan amunisi tentara.

Penumpasan PGRS/Paraku oleh militer mengalami kegagalan. Militer 
juga meminta dukungan mantan Gubernur Kalimantan Barat Oevang Oeray supaya orang Dayak dapat membantu tentara untuk menumpas para pemberontak. Masyarakat Dayak dihimbau untuk ikut berpartisipasi bersama tentara untuk menumpas PGRS/Paraku. Militer melakukan propaganda di kalangan tokoh Dayak dengan menyebarkan beberapa isu bahwa orang-orang komunis tidak menyukai sistem Dayak. Mereka dikoordinasikan Kodam XII Tanjungpura. Para pemuka Dayak diprovokasi dan ditanamkan pengertian bahwa PGRS/Paraku adalah komunis yang tidak beragama dan orang Dayak tidak bisa hidup bersama-sama komunis. Dijelaskan pula bahwa PGRS/Paraku adalah Cina Sarawak yang ingin memecah belah keamanan wilayah RI.

Para pemimpin Dayak menemui Oevang Oeray untuk membicarakan pengusiran orang Cina dari pedalaman. Pertemuan diadakan di Pontianak. Hasil pertemuan diikuti dengan pengumuman di radio agar orang Dayak melakukan pengusiran. Oevang menulis surat dan membacakannya sendiri di radio Radio Republik Indonesia (RRI) Pontianak yang berisi orang Cina harus meninggalkan wilayahnya dan pindah ke kota kecamatan terdekat. Pengumuman diikuti surat undangan menghadiri pertemuan pada 11 Oktober 1967. Seluruh kepala kampung di Kewedanan Bengkayang, diminta datang ke Samalantan. Pertemuan dihadiri Oevang dan dijaga ketat tentara. Oevang memerintahkan kepada seluruh kepala kampung, bersiap-siap menunggu hari yang disebutnya Gerakan Demonstrasi.

\section{Pembelajaran Sejarah Lokal}

Pembelajaran sejarah sebagai manifestasi pendidikan sejarah bukan hanya berfungsi untuk mentransfer fakta-fakta peristiwa masa lampau kepada peserta didik, melainkan untuk menanamkan nilai-nilai kehidupan di bidang politik, sosial, ekonomi, dan budaya. Peristiwa sejarah merupakan best practices, yaitu pengalaman hidup suatu masyarakat yang bernilai tinggi sehingga dapat dijadikan sebagai acuan dalam membangun kehidupan bermasyarakat, berbangsa, dan bernegara yang lebih baik.

Mengingat nilai sejarah bersifat paradoksal, maka perlu ditetapkan batasan atau titik tolaknya. Nilai sejarah ditentukan atas dasar nilai kemasakiniannya. Apa yang terjadi 
sekarang merupakan kontinuitas dari masa lampau. Oleh karena itu, proses interaksi yang terus menerus antara sejarawan dan fakta-fakta sejarah merupakan bagian terpenting dalam memahami paradoksal nilai sejarah. Dengan demikian, hakikat belajar sejarah merupakan upaya untuk menghubungkan masa lampau dan masa kini atau yang akan datang sehingga diperoleh manfaat untuk kepentingan hidup manusia. Hal ini sesuai dengan pendapat bahwa hakikat belajar adalah “... is that it is a continous proces of interaction between the historian and his facts, an unending dialoque between the present and the past' (Carr, E.H, 1973: 53).

Pentingnya sejarah dalam kehidupan umat manusia tidak perlu diragukan lagi. Sartono Kartodirdjo menyatakan bahwa “... tidak mengetahui sejarah dapat diibaratkan orang membaca buku roman hanya halaman terakhir-nya, karena tidak diketahui "intrige" cerita itu dan "happyend"-nya tidak dapat dimengerti dengan sungguh-sungguh" (Kartodirdjo, 1968: 8). Arti pentingnya sejarah dapat disimak melalui pernyataan berikut:

Knowing yourself means knowing what you can do and since nobody knows what he can do until he tries, the only clue to what man can do is what man has done. The value of history, then, is that it teaches us what man has done and the what man is (Collingwood, 1973: 10). Menurut CP. Hill (1956:35) dalam proses belajar mengajar mata pelajaran sejarah terdapat dua komponen yang berpengaruh bagi keberhasilan siswa yaitu komponen guru dan komponen subjek belajar. Guru berperan sebagai pemimpin yang bertugas mengorganisir dan mempengaruhi perilaku tertentu sehingga terjadi proses belajar mengajar sejarah yang dapat mengkondisikan agar siswa tetap mempunyai hubungan yang hidup dengan mata pelajaran itu sendiri.

Dari penjelasan di atas, maka pengertian pengajaran sejarah dapat diartikan sebagai sebuah aktivitas yang dapat memberikan kemungkinan untuk menciptakan sebagai kegiatan yang bertujuan untuk menanamkan pengertian tentang peranan sejarah dalam masyarakat.

\section{METODE PENELITIAN}

\section{Bentuk Penelitian}


Strategi dalam penelitian ini adalah penelitian studi kasus terpancang (embedded research), yaitu penelitian kualitatif yang sudah menentukan fokus penelitiannya (Yin dalam H. B. Sutopo, 2006: 39), sehingga dalam pengambilan data terlebih dahulu sudah ditetapkan obyek penelitiannya dalam rangka mendapatkan informasi atau fakta sesuai dengan harapan peneliti yaitu berupa penelusuran fakta sejarah mengenai hegemoni yang ada dalam peristiwa pemberantasan PGRS-Paraku tahun 1967 di Kalimantan Barat.

\section{Sumber Data}

Data atau informasi yang paling penting untuk dikumpulkan dan dikaji dalam penelitian ini sebagian besar berupa data kualitatif.

1. Informan atau narasumber dalam penelitian ini adalah Susi Susanti, S.Pdi., M.Pd selaku dosen mata kuliah sejarah lokal, para mahasiswa semester IV Program Studi Pendidikan Sejarah STKIP PGRI Pontianak.

2. Tempat dan peristiwa/aktivitas terdiri dari kegiatan pembelajaran yang dilakukan oleh dosen dalam kelas.
3. Arsip dan dokumen

Arsip dan Dokumen merupakan bahan tertulis yang berkaitan dengan suatu peristiwa atau aktivitas tertentu. Oleh karena itu dokumen dan arsip bukan hanya menjadi sumber data yang penting bagi penelitian kesejarahan, tetapi juga dalam penelitian kualitatif pada umumnya (Sutopo, 2006: 61-62).

\section{Instrumen Penelitian}

Instrumen yang digunakan dalam penelitian ini adalah panduan observasi, panduan wawancara dan lembar telaah dokumen.

\section{Validitas Data}

Secara umum dalam penelitian kualitatif teknik pengembangan validitas data yang digunakan adalah teknik trianggulasi (Patton, 1980: 161).

\section{Trianggulasi data (Data Triangulation)}

Trianggulasi sumber adalah teknik trianggulasi yang dilakukan dengan mengumpulkan data sejenis dari beberapa sumber data yang berbeda. Dalam penelitian ini pemberantasan PGRS-Paraku di Kalimantan 
Barat tahun 1967 (kajian teori hegemoni Gramsci untuk pembelajaran sejarah lokal), dan alasan diterapkannya pemberantasan PGRS-Paraku di Kalimantan Barat tahun 1967 (kajian teori hegemoni Gramsci untuk pembelajaran sejarah lokal) dan hasil setelah diterapkannya pendidikan ini dapat digali dari sumber data yang berbeda berupa informan/ narasumber, peristiwa/ aktivitas dan arsip/ dokumen.

\section{Triangulasi teori (Theory triangulation)}

Menggunakan beragam perspektif untuk menginterpretasikan sekelompok data tunggal. Trianggulasi jenis ini dilakukan oleh peneliti dengan menggunakan perspektif lebih dari satu teori dalam membahas permasalahan yang dikaji. Maka dari itu dalam melakukan trianggulasi teori, peneliti wajib memahami teori-teori yang digunakan dan keterkaitannya dengan permasalahan yang diteliti sehingga mampu menghasilkan simpulan yang lebih mantap, bisa dipertanggungjawabkan dan benar-benar memiliki makna yang mendalam serta bersifat multiperspektif (Sutopo, 2006: 99).

\section{Trianggulasi metodelogis} (methodological

trianggulation)

Trianggulasi metode adalah teknik trianggulasi yang dilakukan dengan mengumpulkan data sejenis dengan menggunakan metode yang berbeda.Data sejenis yang dikumpulkan dengan metode yang berbeda dibandingkan dan ditarik simpulan data yang lebih kuat validitasnya (Sutopo, 2006: 95).

\section{Teknik Analisis Data}

Teknik analisis dalam penelitian ini bersifat induktif yaitu teknik analisis yang tidak dimaksudkan untuk membuktikan suatu prediksi atau hipotesis penelitian, tetapi simpulan dan teori yang dihasilkan berbentuk dari data yang dikumpulkan. Sifat analisis induktif menekankan pentingnya apa yang sebenar terjadi di lapangan yang bersifat khusus berdasarkan karakteristik konteksnya. Dalam penelitian ini analisis induktif yang digunakan adalah teknik analisis interaktif, yaitu setiap data yang diperoleh dari lapangan selalu 
diinteraksikan atau dibandingkan dengan unit data yang lain (Sutopo, 2006: 107). Dalam proses analisis interaktif terdapat 4 komponen yang harus dipahami oleh peneliti yaitu: (1) pengumpulan data, (2) reduksi data,(3) sajian data (4) penarikan simpulan/ verifikasi. Empat komponen tersebut harus berkaitan, selalu terlibat dalam proses analisis, dan memberi arahan dalam simpulan serta selalu dibandingkan untuk pemantapan pemahaman. Untuk lebih jelas akan dijelaskan berikut ini.

\section{Pengumpulan data}

Dalam analisis data langkah awal yang perlu dilakukan, peneliti harus mengumpulkan data yang diperoleh sebelum melakukan reduksi. Data yang dikumpulkan bisa data dari lapangan (fieldnotes) dan teori-teori yang berkaitan dengan tema yang diambil peneliti.

\section{Reduksi data (data reduction)}

Reduksi data merupakan proses pemilihan, pemfokusan, penyederhanaan dan abtraksi data kasar yang ada dalam fieldnotes (catatan lapangan).

\section{Sajian data (data display)}

Sajian data merupakan
rakitan organisasi informasi,

deskripsi dalam bentuk narasi lengkap sehingga simpulan penelitian dapat dilakukan.

4. Penarikan simpulan/ verifikasi (conclusion drawing/verifying)

$$
\text { Sejak tahap awal }
$$
pengumpulan data, peneliti harus sudah mulai memahami makna dari berbagai hal yang ditemukan, pernyataan-pernyataan, konfigurasikonfigurasi yang mungkin, alur sebab akibat dari berbagai porsi. Selanjutnya setelah verifikasi dilakukan penarikan simpulan.

SAJIAN DATA DAN

\section{PEMBAHASAN}

\section{Sajian Data}

a. PGRS/Paraku di Kalimantan Barat Terbentuknya PGRS/Paraku tidak dapat dilepaskan dari konflik Indonesia Malaysia. Konflik ini tidak memakan waktu yang terlalu lama, akan tetapi mempunyai pengaruh yang cukup besar bagi perkembangan Indonesia. Sejak awal, pemerintah Indonesia menolak pembentukan Federasi Malaysia yang didukung penuh oleh Inggris.Wilayah Kalimantan Utara juga merupakan daerah koloni Inggris. Seperti halnya Semenanjung Malaya, Kalimanta 
Utara juga dimasukan dalam teritori federasi Malaysia dan tanpa meminta persetujuan dari penduduk Kalimantan Utara. Penolakan penduduk, khususnya warga keturunan Cina (Tionghoa), didasari pada kecemasan akan adanya dominasi warga Melayu semenanjung Malaya terhadap rakyat Kalimantan Utara.

Gerakan PGRS /Paraku dikatakan merupakan suatu gerakan anarkis, sehingga mengganggu stabilitas sosial politik di Kalimantan Barat. Menghadapi kondisi yang demikian, maka diperlukan sikap yang jelas dan tegas dari pemerintah Indonesia untuk menindaklanjuti gerakan PGRS/Paraku tersebut yang dianggap gerakan terlarang dan dipandang sebagai ancaman terhadap Indonesia. Sikiap pmerintah Indonnesia lebih menyangkut pada hubungan internasional, khususnya masalah perbatasan karena daerah operasi PGRS/Paraku bukan hanya di daerah kekuasaan Indonesia. Tetapi juga di Serawak (bagian federasi malaysia), sehingga dalam hal ini pemerintah Indonesia harus memiliki suatu bentuk kerjasama antara Indonesia dengan Malaysia untuk menerapkan prinsip keamanan besama.

b. Analisis teori hegemoni Gramsci terhadap peristiwa pemberantasan PGRS/Paraku

Seperti yang telah dibahas sebelumnya, bahwasannya kemunculan PGRS Paraku tahun 1963 berkaitan dengan kepentingan politik Indonesia, yaitu untuk menangani konfrontasi Indonesia Malaysia, dimana Indonesia pada saat kepemimpinan Soekarno menolak untuk didirikannya Federasi Malaysia oleh Inggris. PGRS/Paraku menjadi sesuatu yang sangat menarik ketika pemerintahan Soeharto seakan-akan menjadi musuh yang paling berbahaya yang harus segera dimusnahkan. Hal ini bukan sesuatu yang aneh, karena anggota PGRS/Paraku menganut paham komunisme, sedangkan Soeharto sebagai tampuk kepemimpinan tertinggi di Indonesia saat itu antipati dengan komunis. Soeharto segera mengeluarkan Tritura untuk membersihkan negara dari segala unsur PKI. 
Dapat kita lihat bahwa PGRS/Paraku terombang-ambing antara dua kekuatan ideologi yang besar dan sangat berpengaruh kala itu. Secara kasar, sosialisme dan komunisme pada masa pemerintahan Soekarno memiliki tempat tersendiri dan dapat dengan bebas menjalankan segala kegiatan mereka. Hal ini disebabkan Soekarno mengusung paham Nasakom dalam menjalankan pemerintahannya. Akan tetapi setelah tumbangnya Soekarno, kondisi politik di Indonesia mulai berubah haluan. Kebijakan Tritura yang dilakukan Soeharto terlihat adanya keinginan untuk menciptakan suatu hegemoni agar konsep kehidupan yang ditawarkan Soeharto dapat diterima oleh rakyat Indonesia.

Antonio Gramsci, seorang tokoh pembeharuan terhadap konsep Marxis menyatakan bahwa hegemoni atau dominasi merupakan suatu bentuk supremasi suatu kelompok atau beberapa kelompok atas yang lainnya, atas bentuk supremasi yang lain yang dinamakan "dominasi" yaitu kekuatan yang ditopang oleh kekuatan fisik. Sejalan dengan pemerintahan baru di bawah Soeharto memaksa rakyat menerima nilai-nilai dan ideologi yang terus diperjuangkan dan dipertahankan oleh pihak yang dominan, sehingga pihak yang didominasi tetap diam dan taat terhadap dominasi kepemimpinan penguasa.

c. Pembelajaran sejarah lokal melalui materi peristiwa pemberantasan PGRS-Paraku

Pembelajaran sejarah lokal dilaksanakan di kelas A pagi semester IV program studi pendidikan sejarah. Pembelajaran dilaksanakan pada hari Rabu, tanggal 14 Mei 2014. Dalam proses pembelajaran sejarah lokal, kelas dibagi dalam beberapa kelompok dimana masing-masing kelompok mendapatkan materi sejarah lokal sesuai dengan kurikulum. Salah satunya adalah materi PGRS/Paraku.Materi PGRS/Paraku disampaikan melalui sebuah diskusi. Mahasiswa antusias ketika mengikuti proses pembelajaran, baik ketika sesi tanya jawab maupun mendengarkan penjelasan dari dosen, hal ini dikarenakan 
PGRS/Paraku merupakan salah satu peristiwa yang fenomenal. PGRS/Paraku tersebut merupakan peristiwa sejarah lokal yang dapat menambah pengetahuan dan wawasan baru bagi mahasiswa, menumbuhkan kesadaran mahasiswa untuk menggali sejarah yang ada di daerah mereka serta meningkatkan rasa nasionalisme dan jiwa patriotisme.

Proses diskusi didampingi oleh Susi Susanti,S.Pdi.,M.Pd selaku dosen pengampu mata kuliah sejarah lokal. Dosen memberikan kebebasan pada mahasiswa untuk berdiskusi. Setelah diskusi ditutup, dosen menjelaskan kembali materi PGRS/Paraku. Memberikan analisis tambahan terhadap peristiwa PGRS/Paraku. Pada akhir pembelajaran, bersama-sama dengan mahasiswa menyimpulkan materi pembelajaran.

\section{Pembahasan}

1. Pemberantasan PGRS/Paraku di Kalimantan Barat

Dalam mengkaji kaitan hegemoni kekuasaan Soeharto dalam pemberantasan PGRS/Paraku, tidak dapat dilepaskan dari politik Soekarno dan Soeharto. Maka dari itu disini akan dibahas sedikit tentang politik Soekarno dan Soeharto serta kontribusinya dalam pembentukan dan pemberantasan PGRS/Paraku di Kalimantan Barat.

Pada masa Demokrsi Terpimpin ini PKI mendapatkan kedudukan penting. Kader-kader PKI banyak yang duduk dalam DPR-GR, DPA dan Pengurus Besar Front Nasional serta daerah. Berangkat dari dukungan Soekarno terhadap PKI dan menjadikan PKI sebagai garis depan dalam pemerintahannya, sudah jelas terlihat ke arah mana politik yang diusung oleh Soekarno. Dari sini akan membawa kita pada bagaimana kontribusi komunis di Kalimantan Barat dalam pemerintahan dan proyek politik Soekarno.

Kalimantan Barat merupakan salah satu wilayah Indonesia yang berada dalam satu daratan dengan Malaysia dan Brunei. Inggris berusaha untuk menggabungkan koloni-koloninya di Asia Tenggara dalam satu kesatuan. Malaysia yang berada di 
bawah negara persemakmuran, segera mendekat ke Inggris. Rencana tersebut ditentang oleh Pemerintahan Indonesia. Presiden Soekarno berpendapat bahwa Malaysia hanya sebuah boneka Inggris, dan konsolidasi Malaysia hanya akan menambah kontrol Inggris di kawasan ini, sehingga mengancam kemerdekaan Indonesia.

Sebagai usaha menentang pembentukan Federasi Malaysia, Soekarno menyerukan Ganyang Malaysia dan mengumpulkan para relawan. Relawan ini banyak terdiri dari orang-orang Cina. Perkembangan selanjutnya kelompok ini membentuk Pasukan Rakyat Kalimantan Utara (Paraku) ataupun Pasukan Gerilya Rakyat Serawak (PGRS) yang mayoritas etnis Tionghoa. Kedua pasukan tersebut dibawah komanado Brigadir Jenderal Supardjo, yang pada saat itu menjabat sebagai Panglima Komando Tempur IV Mandau dengan pusat kedudukan di Bengkayang, Kalimantan Barat. Untuk itu, Resimen Khusus Angkatan Darat (RPKAD) ditugaskan untuk melatih sukarelawan tersebut.

Menjelang akhir 1965, Jendral Soeharto memegang kekuasaan di Indonesia setelah berlangsungnya G30S/PKI. Oleh karena konflik domestik ini, keinginan Indonesia untuk meneruskan perang dengan Malaysia menjadi berkurang dan peperangan pun mereda. Tetapi setelah Soeharto dapat duduk dalam tampuk kepemimpinan Indonesia, berlangsung pembantaian orangorang yang dianggap komunis.Hal ini dikarenakan bedanya pandangan ideologi Soeharto dengan komunis. Usaha untuk menghabisi komunis di Kalimantan Barat baru terjadi setelah adanya rekonsiliasi dengan Malaysia.

\section{Rekonsialisai} dan Perubahan politik menyebabkan Indonesia tidak lagi sejalan dengan politik PGRS-Paraku. Justru menciptakan situasi yang kacau, menjadikan PGRS/Paraku sebagai pendatang liar di daerah perbatasan Serawak dan Kalimantan Barat. Mereka hidup bergerilya, terjepit di antara tentara Indonesia dan Malaysia. Operasi untuk menumpas 
gerilyawan PGRS/Paraku berjalan sangat sulit, karena PGRS/Paraku selalu menghindari pertempuran terbuka. Dengan jumlah personil dan persenjataan yang terbatas mereka hanya beroperasi di hutanhutan. Orang-orang yang simpati kepada PGRS/Paraku masuk ke hutan Kalimantan Barat untuk bergabung dengan mereka di sana. Bulan Juli 1967 PGRS-Paraku menyerang pangkalan udara militer Indonesia di Sanggauledo.Beberapa perwira dan staffnya dibunuh. Mereka juga merebut senjata dan amunisi tentara.

Penumpasan PGRS/Paraku oleh militer mengalami kegagalan. Salah satu penyebab kegagalan tersebut adalah terbatasnya pihak militer setempat baik dalam hal persenjataan maupun dari segi jumlah personil militer yang ada. Mengingat keterbatasan militer setempat, pemerintah mendatangkan pasukan dari Jawa untuk membantu proses penumpasan PGRS-Paraku. Pasukan yang didatangkan yaitu pasukan divisi Siliwangi. Pasukan ini tidak menguasai medan operasi, oleh karena itu mereka merekrut beberapa warga sipil sebagai pasukan terdepan. Mereka yang direkrut adalah yang dinilai menguasai medan operasi sebagai penunjuk jalan. Terbentuklah pasukan-pasukan tambahan seperti pasukan Kancil dan pasukan Kalajengking. Mereka dipersenjatai lengkap dengan seragam militernya.

Militer juga meminta dukungan mantan Gubernur Kalimantan Barat Oevang Oeray supaya orang Dayak dapat membantu tentara untuk menumpas para pemberontak. Masyarakat Dayak dihimbau untuk ikut berpartisipasi bersama tentara untuk menumpas PGRS/Paraku. Militer melakukan propaganda di kalangan tokoh Dayak dengan menyebarkan beberapa isu bahwa orang-orang komunis tidak menyukai sistem Dayak.

2. Analisis teori hegemoni Gramsci terhadap peristiwa pemberantasan PGRS/Paraku

Dalam pandangan postmodernisme, teori hegemoni menjadi sudut pandang kajian peristiwa pemberanguasan PKI dalam artian PGRS/Paraku. Secara 


literal, hegemoni $r$
kepemimpinan. Secara
hemati
hegemoni merupakan $r$ suatu
dominasi suatu pihak dalam seluruh
aspek. Hegemoni bukanlah
hubungan dominasi dan
$\begin{aligned} & \text { menggunakan } \\ & \text { hegemoni adalah hubungan } \\ & \text { persetujuan dan menggunakan }\end{aligned}$
kepemimpinan politik-ideologis.

Soeharto memaksakan agar rakyat menerima nilai-nilai dan ideologi yang terus diperjuangkan dan dipertahankan oleh pihak yang dominan, sehinggga pihak yang didominasi tetap diam dan taat terhadap dominan kepemimpinan penguasa.Analisis utama hegemoni dalam peristiwa mangkok merah yang didalamnya berusaha untuk memberantas PGRS/Paraku adalah bagaimana Soeharto memberikan kuasa politik ideologisnya dalam usaha untuk memberantas PGRS/Paraku.

Melalui konsep hegemoni, Gramsci beragumentasi bahwa kekuasaan agar dapat abadi dan langgeng membutuhkan paling tidak dua perangkat kerja. Pertama, adalah perangkat kerja yang mampu melakukan tindak kekerasan yang bersifat memaksa atau dengan kata lain kekuasaan membutuhkan perangkat kerja yang bernuansa law enforcemant. Perangkat kerja yang pertama ini biasanya dilakukan oleh pranata negara (state) melalui lembagalembaga seperti hukum, militer, polisi dan bahkan penjara. Dalam peristiwa ini lembaga yang paling menonjol adalah militer, tepatnya $\mathrm{AD}$ yang sangat memainkan peranan yang dominan sekali.AD menjadi garda terdepan dalam pemberantasan anggota PGRS/Paraku ini. Dan Soeharto memberikan kontrol yang sangat ketat. Soeharto berusaha keras untuk melaksanakan tritura, yang digembar-gemborkan dalam upaya kudeta secara harus kepemimpinan Soekarno.

Perangkat kerja yang kedua, adalah perangkat kerja yang mampu membujuk masyarakat beserta pranata-pranata untuk taat pada mereka yang berkuasa melalui kehidupan beragama, pendidikan, kesenian dan bahkan juga keluarga (Heryanto, 1997). Dalam memantapkan hegemoni kekuasaannya, Soeharto bersama 
dengan AD memanfaatkan kelompok etnis Dayak.mereka menyebarkan propaganda kepada orang-orang Dayak akan betapa bahayanya ajaran komunisme, dan komunisme tidak menyukai sistem Dayak, sehingga komunisme harus dibumihanguskan. Dalam hal ini orang-orang yang tergabung dalam PGRS/Paraku adalah etnis Tionghoa yang pro-komunis. Namun demikian, semua etnis Tionghoa bagi orang-orang Dayak adalah komunis, sehingga memunculkan salah persepsi yang mengakibatkan peristiwa Mangkok Merah tidak sekedar kepentingan politik dominasi kekuasaan, namun jauh dari itu berubah menjadi konflik etnis yang cukup berbahaya. Kedua level ini pada satu sisi berkaitan dengan fungsi hegemoni dimana kelompok dominan menangani keseluruhan masyarakat dan disisi lain berkaitan dengan dominasi langsung atau perintah yang dilaksanakan diseluruh negara dan pemerintahan yuridis (Gramsci, 1971).

Kedua hal tersebut sangat penting untuk membentuk sebuah negara integral. Komninasi kompleks antara "kedidaktoran dan hegemoni" atau seluruh kompleks aktivitas praktis dan teoritis dimana kelas berkuasan tidak hanya menjustifikasi dan menjaga dominannya, tetapi juga berupaya memenangkan persetujuan aktif dari mereka yang dikuasai (Netzar; 2009: 151). Dalam membentuk Negara integral, Soeharto cenderung menggunakan paksaan, terutama kepada masyarakat sipil agar mau dan bisa menerima ideologi yang dibawanya. Apabila ideologi sudah berhasil ditanamkan, maka aspek yang lain, misalnya ekonomi dan politik akan sangat mudah untuk dikontrol, sehingga akan sangat mudah untuk mewujudkan Negara integral yang terdiri dari masyarakat sipil dan masyarakat politik. Walaupun dalam keberlangsungannya akan sangat terlihat adanya kediktatoran yang berujung pada hegemoni.

3. Pembelajaran sejarah lokal melalui materi peristiwa pemberantasan PGRS-Paraku

Kajian peristiwa pemberantasan PGRS/Paraku melalui kajian hegemoni Gramsci dapat menjadi suatu materi 
pembelajaran sejarah lokal.

Mahsiswa dapat menggali sejarah lokal yang ada dan dapat menambah pengetahuan baik bagi mahasiswa maupun dosen serta dapat meningkatkan rasa nasionalisme pada mahasiswa generasi yang akan datang. Sejarah lokal mengangkat peristiwaperistiwa lokal atau kedaerahan. Sejarah lokal ini lah yang nantinya akan membentuk sejarah nasional.

Melalui pembelajaran sejarah lokal dapat menumbuhkan kesadaran terhadap daerah masingmasing. Hal ini disebabkan sejak sekolah dasar hingga perguruan tinggi, pembelajaran sejarah hanya diutamakan mempelajari sejarah yang berskala nasional. Sehingga siswa tidak dapat mengetahui sejarah daerah mereka. Dengan duduk di bangku kuliah dan memepelajari sejarah lokal memberikan keuntungan sendiri untuk mahasiswa, selain mereka dapat mengetahu sejarah daerah mereka masing-masing, mereka dapat pula mengkaitkan peristiwa nasional serupa yang sezaman dengan peristiwa yang ada di daerah mereka.

\section{KESIMPULAN}

Berdasarkan pembahasan penelitian yang telah diuraikan ditas maka dapat ditarik kesimpulan bahwa PGRS/Paraku dibentuk ketika Orde Lama dibawah kepemimpinan Soekarno. Mereka dibentuk ketika terjadi konfrontasi antara Indonesia Malaysia, dimana Soekarno tidak setuju terhadap pembentukan Federasi Malaysia. Sikap Soekarno ini didukung oleh rakyat Kalimantan Utara. Namun ketika Orde Baru, kondisi menjadi berubah. PGRS/Paraku yang dulunya menjadi garda terdepan dalam konfrontasi akhirnya diperangi dan dibumihanguskan. Bahkan konflik ini menjadi konflik yang lebih jauh menjadi sebuh konflik rasialis.

Teori hegemoni Gramsci membantu dalam menganalisis peristiwa pemberantasan PGRS/Paraku. Hegemoni merupakan alat untuk melanggengkan kekuasaan. Dalam penumpasan PGRS/Paraku sebagai bentuk kecil hegemoni di Kalimantan Barat, tindakan kekerasan yang bersifat memaksa dilakukan oleh militer, dalam hal ini adalah angkatan darat. AD menjadi garda terdepan dalam pemberantasan anggota PGRS/Paraku. Soeharto memberi kontrol yang sangat 
ketat untuk dapat mengendalikan situasi di lapangan. Soeharto berusaha keras untuk melaksanakan Tritura, yang digembar-gemborkan dalam upaya kudeta secara halus di bawah kepemimpinan Soeharto. Selain dengan kekuatan militer, bantuan dari rakyat Dayak merupakan hal unik. Masyarakat Dayak di daerah perbatasan menghimpun kekuatan bersama-sama ABRI melawan komunis yang telah memcah belah mereka dan menumpas PGRS/Paraku.

Kajian peristiwa pemberantasan PGRS/Paraku melalui kajian hegemoni Gramsci dapat menjadi suatu materi pembelajaran sejarah lokal. Mahsiswa dapat menggali sejarah lokal yang ada dan dapat menambah pengetahuan baik bagi mahasiswa maupun dosen serta dapat meningkatkan rasa nasionalisme pada mahasiswa generasi yang akan datang. Sejarah lokal mengangkat peristiwa-peristiwa lokal atau kedaerahan. Sejarah lokal ini lah yang nantinya akan membentuk sejarah nasional.

\section{DAFTAR PUSTAKA}

Carr, E.H. 1973. What is History. New York: Alfred A Knopf.

Collingwood, I.G. 1973.The Ideas of History. London: Oxford University Press.
Hidayat Mukmin. 1991. TNI Dalam politik Luar Negeri: Studi kasus Penyelesaian Konfrontasi IndonesiaMalaysia. Jakarta: PustakaSinar Harapan.

Komandan Korem 121/Alambhana Wanawwai.1993. Peranan ABRI dan Masyarakat dalam Penumpasan Gerakan PGRS/PARAKU di Kalimantan Barat.Pontianak: Komandan Daerah Militer VI Tanjungpura, Komandan Resort Militer 121.

Machrus Effendy. 1995. Penghancuran PGRS-PARAKU dan PKI di kalimantan Barat. Jakarta: PT. Dian Kemilau Jakarta.

Nurcahyani, 1. 2002.Pemberontakan PGRS/PARAKU di Kalimantan Barat.Pontianak: Badan Pengembangan Kebudayaan dan Parowisata Deputi Bidang Pelestarian dan Pengembangan Budaya Balai Kajian Sejarah dan Nilai Tradisional.

Patria, Nezar dan Arief, Andi.2009. Antonio Gramsci Negara dan Hegemoni. Yogyakarta: Pustaka Pelajar.

Roger Simon. 2004. Gagasan-Gagasan Politik Gramsci. Yogyakarta: INSIST dan Pustaka Pelajar.

SEDAM XII/Tanjungpura. 1970. Tandjungpua Berdjuang. Pontianak: Kodam XII Tanjungpura.

Sumadi. 1974. Peranan Kalimantan Barat dalam Menghadapi Subversi Komunis Asia Tenggara. Pontianak: Yayasan Tanjungpura.

Sutopo, H.B. 2006.Metodologi Penelitian Kualitatif. Surakarta: UNS Press. 
